\title{
Analysis of demographic and socioeconomic factors that influence morbidity through depressive disorder
}

\author{
Analiza factorilor demografici şi socioeconomici care influențează \\ morbiditatea prin tulburare depresivă
}

\author{
Mariana Valy Besoiu ${ }^{1,2}$, Petru Armean ${ }^{1}$ \\ ${ }^{1}$ Universitatea de Medicină și Farmacie „Carol Davila“, București, România \\ 2Spitalul de Psihiatrie Titan „Dr. Constantin Gorgos“, București, România
}

\begin{abstract}
Depressive disorder can be the result of a complex interaction of social, psychological and biological factors. The study aimed to identify the demographic and socioeconomic characteristics of patients with depressive disorder hospitalized in "Dr. Constantin Gorgos" Titan Psychiatric Hospital during 2015-2018.

In order to identify the differences between the population subgroups in terms of demographic and professional characteristics, a group of 1,217 continuously hospitalized patients and 2,040 day hospitalized patients in the Psychiatric Hospital "Constantin Gorgos" Titan in 2014-2018 was studied. The study is descriptive and, in the study, secondary data from the hospital database were analyzed.

The analyzed data were collected during the hospitalization of patients with recurrent depressive disorder. The study identified differences between the analyzed subpopulations, differences that were similar to those identified in the literature. Thus, it was found that more women than men accessed the psychiatric medical services, the biggest difference between the distributions being found in the age group 50-59 years. A small proportion of patients have completed higher education and most of them are retired before reaching the standard retirement age. Most of them come from urban areas.
\end{abstract}

Keywords: depression, demographic factors, socioeconomic factors

\section{REZUMAT}

Tulburarea depresivă poate fi rezultatul unei interacțiuni complexe a factorilor sociali, psihologici și biologici. Studiul a avut ca scop identificarea caracteristicilor demografice şi socioeconomice ale pacienților cu tulburare depresivă internați în Spitalul de Psihiatrie Titan „Dr. Constantin Gorgos“ în perioada 2015-2018.

Pentru identificarea diferențelor dintre subgrupele populaționale, din punctul de vedere al caracteristicilor demografice și profesionale, a fost luat în studiu un lot constituit din 1.217 pacienți spitalizați continuu și 2.040 spitalizați de zi în Spitalul de Psihiatrie Titan „Dr. Constantin Gorgos“ în perioada 2014-2018. Studiul este de tip descriptiv și, în cadrul studiului, au fost analizate date secundare provenite din baza de date a spitalului.

Datele analizate au fost colectate pe parcursul spitalizării pacienților cu tulburare depresivă recurentă. În cadrul studiului, au fost identificate diferențe între subpopulațiile analizate, diferențe care au fost similare celor identificate în literatura de specialitate. Astfel, s-a constatat că au accesat serviciile medicale de psihiatrie mai multe femei decât bărbați, cea mai mare diferență între distribuții constatându-se la grupa de vârstă 50-59 de ani. O mică pondere dintre pacienți au finalizat studii superioare și majoritatea dintre ei sunt pensionați înaintea împlinirii vârstei standard de pensionare. Cei mai mulţi dintre ei provin din mediul urban.

Cuvinte cheie: depresie, factori demografici, factori socioeconomici

\section{INTRODUCERE}

Tulburarea depresivă este o afecțiune frecventă la nivel mondial, cu peste 264 de milioane de per- soane afectate (1). Mai ales când este de lungă durată şi cu intensitate moderată sau severă, depresia poate fi considerată o afecțiune gravă de sănătate, 
care poate determina persoana afectată să sufere foarte mult și să funcționeze slab la locul de muncă, la școală și în familie, putând duce chiar la sinucidere. Deși există tratamente eficiente pentru tulburările mintale, între $76 \%$ și $85 \%$ dintre persoanele din țările cu venituri mici și medii nu primesc niciun tratament pentru tulburarea lor (2). Barierele pentru îngrijirea eficientă a tulburării depresive includ lipsa resurselor, lipsa personalului medical instruit și stigmatul social asociat, în general, cu tulburările mintale.

Tulburarea depresivă poate fi rezultatul unei interacțiuni complexe a factorilor sociali, psihologici și biologici. Persoanele care au trecut prin evenimente adverse de viață (șomaj, pierderea unei rude apropiate, traume psihologice) au mai multe șanse să dezvolte depresie. La rândul său, depresia poate duce la mai mult stres şi disfuncție și agravează situația vieții persoanei afectate și depresia în sine.

\section{SCOP}

Identificarea caracteristicilor demografice şi socioeconomice ale pacientilor cu tulburare depresivă internați în Spitalul de Psihiatrie Titan „Dr. Constantin Gorgos“ în perioada 2015-2018.

\section{OBIECTIVE}

Studiul şi-a propus trei obiective principale: identificarea diferențelor din punctul de vedere al vârstei, genului, mediului de rezidență, nivelului de studii între subgrupurile de pacienți incluse în cercetare; identificarea categoriilor profesionale cele mai afectate de existența unei tulburări depresive; evaluarea impactului bolii asupra pensionării pacienților cu tulburare depresivă.

\section{METODE}

Studiul este de tip descriptiv și pentru analiză au fost utilizate date secundare preluate din baza de date a Spitalului de Psihiatrie Titan „Dr. Constantin Gorgos", înregistrate în urma spitalizărilor continue ale pacienților și a serviciilor medicale psihiatrice primite în staţionarul de zi al spitalului.

Pentru a atinge scopul şi obiectivele specifice ale acestui segment al cercetării, au fost luați în studiu 1.217 pacienți, dintre care 982 femei, internați în secția Psihiatrie Acuți din Spitalul de Psihiatrie Titan „Constantin Gorgos“ în perioada 2014-2018 și 2.040 pacienți tratați în staționarul de zi al spitalului în aceeași perioadă, dintre care 1.545 femei.
Pentru pacienții spitalizați în secția Psihiatrie acuți, s-au luat în calcul toate spitalizările pe care aceștia le-au avut în perioada menționată.

Populația țintă a studiului este reprezentată de populația pacienților cu tulburare depresivă recurentă, spitalizați continuu sau tratați în staționarul de zi pentru un episod acut fără simptome psihotice.

Pentru realizarea cercetării, a fost realizată o bază de date conținând, pentru fiecare pacient spitalizat luat în studiu, următoarele variabile:

- vârstă;

- gen;

- localitate de domiciliu;

- mediu de rezidență;

- nivelul studiilor;

- profesie.

Pentru variabila ,vârstă“ a fost considerată vârsta în ani împliniți la momentul internării. Pentru variabila „localitatea de domiciliu“ a fost reținut în studiu sectorul din București în care pacientul își avea domiciliul sau orașul de reședință.

Pentru variabila ,nivelul de studii“ a fost luat în considerare ultimul nivel de studii absolvit, clasificarea nivelului de studii fiind tot cea utilizată de INSSE. Durata de spitalizare (exprimată în zile) a fost considerată diferența între data externării și data internării.

Strategia de cercetare a implicat împărțirea populației de studiu în subpopulaţii relevante pentru obiectivele de cercetare, astfel fiind posibile comparațiile între subpopulația de femei și cea de bărbați, între grupele de vârste, între subpopulațiile împărțite pe niveluri de studii, pe medii de rezidență, profesie.

\section{REZULTATE}

Prima observație care se poate face în lotul studiat este predominența femeilor, aspect care se păstrează în toată perioada studiată (2015-2018), atât în secția cu paturi, cât și în staționarul de zi (figurile 1 şi 2).

În structura cu paturi de spitalizare continuă, acestea au avut un număr mediu de spitalizări de 1,86 în perioada 2015-2018, față de bărbați, care au avut o medie de 1,74 spitalizări, această diferență nefiind semnificativă statistic. Genul feminin a fost asociat semnificativ statistic cu spitalizarea continuă (test $\chi 2, p<0,05$ ).

Din figura 1 , se poate observa și că numărul absolut al spitalizărilor continue pentru diagnosticul studiat a scăzut progresiv din 2015 până în anul 2018, atât pentru femei, cât și pentru bărbați, cea 


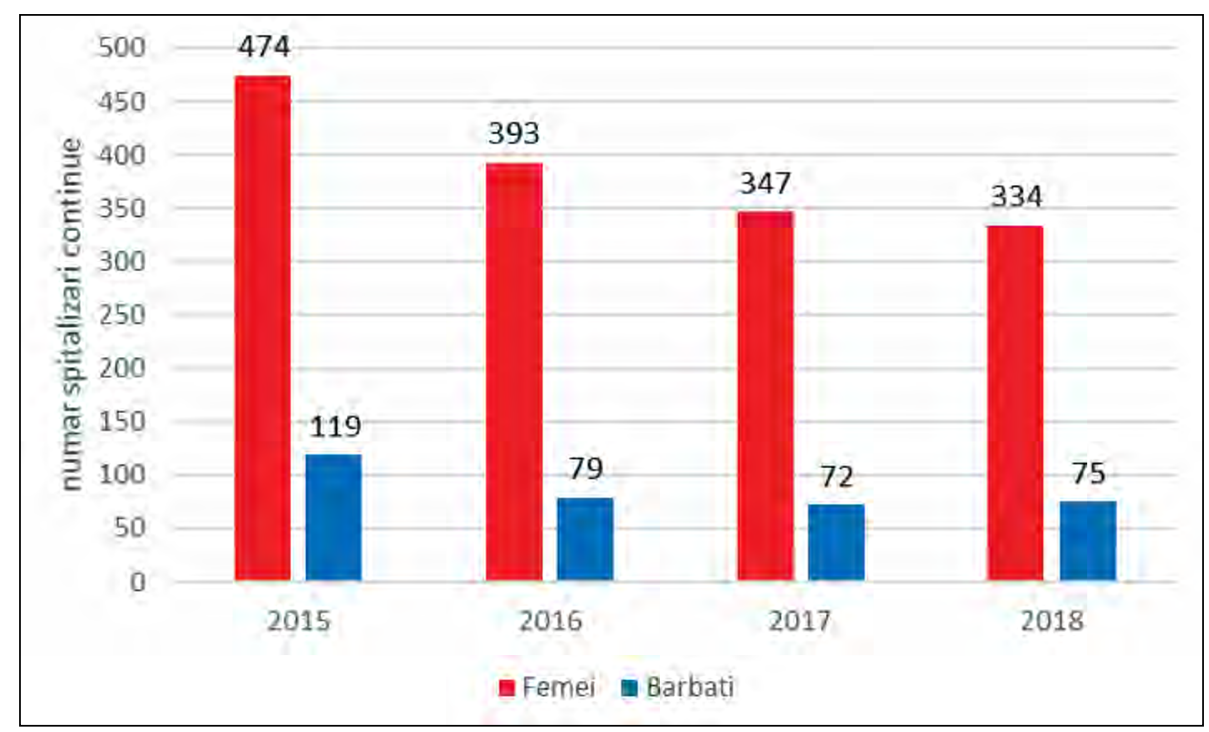

FIGURA 1. Componența lotului studiat pe ani, în perioada 2015-2018, pentru spitalizări continue

mai mare scădere apărând între 2015 și 2016. Numărul externărilor continue a scăzut cu aproximativ $30 \%$ pentru femei și aproape cu $40 \%$ pentru bărbați în perioada 2015-2018.

Același aspect se remarcă și pentru spitalizările de zi (Figura 2), cu deosebirea că scăderea cea mai importantă este între 2016 şi 2017. Scăderea numărului de spitalizări de zi între 2015 şi 2018 este chiar mai accentuată decât scăderea numărului de spitalizări continue.

Vârsta medie a pacienților spitalizați continuu a fost de 55,65 ani (SD $\pm 9,06)$, iar varsta medie a pacienților spitalizați în spitalizare de zi a fost de $55,47$ ani ( $\mathrm{SD} \pm 5,39)$. Diferența între cele două medii nu a fost semnificativă statistic (test t Student, $\mathrm{p}>0,05)$.
Vârsta medie a femeilor a fost semnificativ mai mică (test $\mathrm{t}$ Student, $\mathrm{p}<0,05$ ) atât în spitalizarea continuă, cât și în spitalizarea de zi (Tabel 1).

TABEL 1. Vârsta medie comparativ femei-bărbați în spitalizarea de zi și în spitalizarea continuă, perioada 2015-2018

\begin{tabular}{|l|c|c|}
\hline \multirow{2}{*}{ Tipul spitalizării } & \multicolumn{2}{|c|}{ Vârstă medie (ani) } \\
\cline { 2 - 3 } & Femei & Bărbați \\
\hline Spitalizare continuă & $55,37(S D \pm 9,29)$ & $56,77(S D \pm 7,96)$ \\
\hline Spitalizare de zi & $54,67(S D \pm 5,1)$ & $57,98(S D \pm 5,51)$ \\
\hline
\end{tabular}

Grupa de vârstă modală pentru spitalizarea continuă este 50-59 de ani, urmată de grupa de vârstă 40-49 ani şi apoi de grupa 60-69 ani. Distribuția pe grupe de vârstă este asemănătoare între femei si bărbați, cu o uşoară concentrare spre vârstele mari

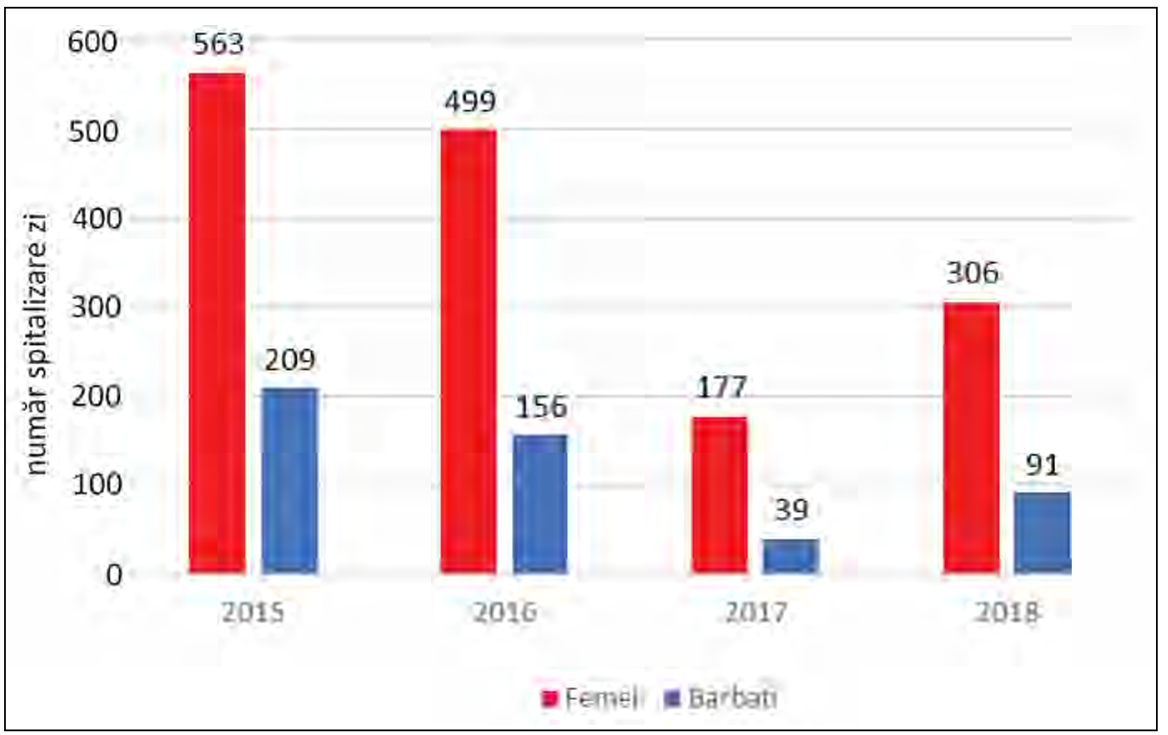

FIGURA 2. Componența lotului studiat pe ani, în perioada 2015-2018, pentru spitalizări de zi 
pentru bărbați. Același model de distribuție pe grupe de vârstă a fost identificat și pentru spitalizarea de zi.

Cea mai mare diferență între femei și bărbați se regăsește la grupa de vârstă 50-59 de ani, diferența începe să crească la grupa de vârstă 30-39 de ani și începând cu grupa de vârstă 60-69 de ani începe să scadă.

Structura spitalizărilor pe gen, categorii de spitalizare și categoria de vârstă (peste 50 de ani, sub 49 de ani) este prezentată în Tabelul 2.

TABEL 2. Structura spitalizărilor pe gen, categorii de spitalizare și vârstă

\begin{tabular}{|l|c|c|c|c|c|c|}
\hline \multirow{2}{*}{$\begin{array}{l}\text { Categoria } \\
\text { de vârstă }\end{array}$} & \multicolumn{3}{|c|}{$\begin{array}{c}\text { Număr spitalizări } \\
\text { continue }\end{array}$} & \multicolumn{3}{c|}{ Număr spitalizări de zi } \\
\cline { 2 - 7 } & Bărbați & Femei & Total & Bărbați & Femei & Total \\
\hline$>50$ de ani & 347 & 1.447 & 1.794 & 459 & 1.364 & 1.823 \\
\hline$<49$ de ani & 62 & 388 & 450 & 36 & 181 & 217 \\
\hline Total & $\mathbf{4 0 9}$ & $\mathbf{1 . 8 3 5}$ & $\mathbf{2 . 2 4 4}$ & $\mathbf{4 9 5}$ & $\mathbf{1 . 5 4 5}$ & $\mathbf{2 . 0 4 0}$ \\
\hline
\end{tabular}

Vârsta de peste 50 de ani s-a asociat semnificativ statistic cu creșterea numărului de spitalizări continue (test $\chi 2, \mathrm{p}<0,05$ ).

Cea mai mare pondere în lotul studiat o reprezintă pacienții care absolvit liceul ca fiind cel mai înalt nivel de studii finalizat. Această diferență se menține pentru toți anii analizați (Tabel 3). Proporția persoanelor care au absolvit liceul este mai mare semnificativ statistic decât proporția altor categorii legate de nivelul de educație (test $\mathrm{t}$ Student pentru un eşantion, $\mathrm{p}<0,05$ ).

Pentru spitalizările continue, proporția femeilor care au absolvit liceul şi proporția femeilor care au finalizat ciclul gimnazial au fost semnificativ mai mari decât ale bărbaților cu același nivel educațional (test $\chi 2, p<0,05$ ). Pentru aceeaşi categorie de spitalizări, proporția bărbaților a fost semnificativ mai mare pentru cei cu școală profesională, școală postliceală sau studii superioare absolvite față de proporțiile corespondente ale femeilor (test $\chi 2$, $\mathrm{p}<0,05)$.
Rezultatele referitoare la nivelul educaţional și gen sunt prezentate în Figura 3.

Aceleași diferențe între bărbați și femei pot fi observate și la spitalizarea de zi (Figura 4). Astfel, proporția bărbaților cu școală profesională, postliceală sau studii superioare este semnificativ mai mare decât a femeilor pentru aceleași niveluri educaţionale $(p<0,05)$. Similar, proporția femeilor cu liceu sau ciclu gimnazial absolvit este mai mare decât cea a bărbaților $(\mathrm{p}<0,05)$.

Proporția pacienților care au absolvit liceul și a celor cu studii superioare a fost semnificativ asociată cu spitalizarea continuă (test $\chi 2, p<0,05$ ).

Majoritatea pacienților spitalizați in perioada $2015-2018$ provin din mediul urban $(84,4 \%$ dintre cei cu spitalizările continue și 80,63\% dintre cei cu spitalizările de zi). Astfel, au fost înregistrate 1.565 spitalizări continue la femei din mediul urban faţă de 270 la femei din mediul rural, iar pentru bărbați s-au înregistrat 329 spitalizări pentru cei din mediul urban faţă de 80 de spitalizări pentru cei din mediul rural pe toată perioada studiată. Acest aspect ne dă o imagine asupra accesului scăzut al populației din mediul rural la servicii medicale de specialitate în psihiatrie.

Proveniența din mediul urban s-a asociat semnificativ cu spitalizarea continuă (test $\chi 2, p<0,05$ ).

Dintre pacienții cu spitalizare continuă având mediu de rezidență urban, $90,07 \%$ provin din București, iar pentru spitalizarea de zi, 96,71\% dintre pacienți provin din București. Proporția pacienților din spitalizarea de zi care provin din București din totalul pacienților din mediul urban din spitalizarea de zi a fost semnificativ mai mare (test $\chi 2, p<0,05$ ) față de proporția pacienților din spitalizarea continuă care provin din București din totalul pacienților din mediul urban din spitalizarea continuă.

Media de vârstă din spitalizarea de zi nu a diferit semnificativ pentru pacienții proveniți din mediul urban față de cei proveniţi din mediul rural, spre

TABEL 3. Structura lotului studiat în funcție de nivelul de educație, pe ani, în perioada 2015-2018

\begin{tabular}{|l|c|c|c|c|c|}
\hline Nivel studii & An 2015 & An 2016 & An 2017 & An 2018 & $\begin{array}{c}\text { Perioada } \\
\mathbf{2 0 1 5 - 2 0 1 8}\end{array}$ \\
\hline Ciclu primar & $4,66 \%$ & $4,65 \%$ & $4,57 \%$ & $1,92 \%$ & $4,63 \%$ \\
\hline Ciclu gimnazial & $24,44 \%$ & $25,22 \%$ & $25,36 \%$ & $21,86 \%$ & $\mathbf{2 5 , 8 1 \%}$ \\
\hline Liceu & $\mathbf{3 0 , 2 3 \%}$ & $\mathbf{3 1 , 1 3 \%}$ & $\mathbf{3 3 , 6 8 \%}$ & $\mathbf{3 2 , 1 5 \%}$ & $\mathbf{3 0 , 4 3 \%}$ \\
\hline Şcoală postliceală & $3,53 \%$ & $2,33 \%$ & $1,04 \%$ & $0,96 \%$ & $2,56 \%$ \\
\hline Şcoală profesională & $\mathbf{2 6 , 8 4 \%}$ & $\mathbf{2 5 , 9 4 \%}$ & $\mathbf{2 4 , 9 5 \%}$ & $31,18 \%$ & $\mathbf{2 6 , 9 8 \%}$ \\
\hline Studii superioare & $9,18 \%$ & $10,02 \%$ & $9,36 \%$ & $7,71 \%$ & $7,64 \%$ \\
\hline Studii superioare de scurtă durată & $0,42 \%$ & $0,18 \%$ & $0,21 \%$ & $0,32 \%$ & $0,33 \%$ \\
\hline Fără studii/nespecificat & $0,56 \%$ & $0,54 \%$ & $0,42 \%$ & $3,30 \%$ & $1,62 \%$ \\
\hline
\end{tabular}




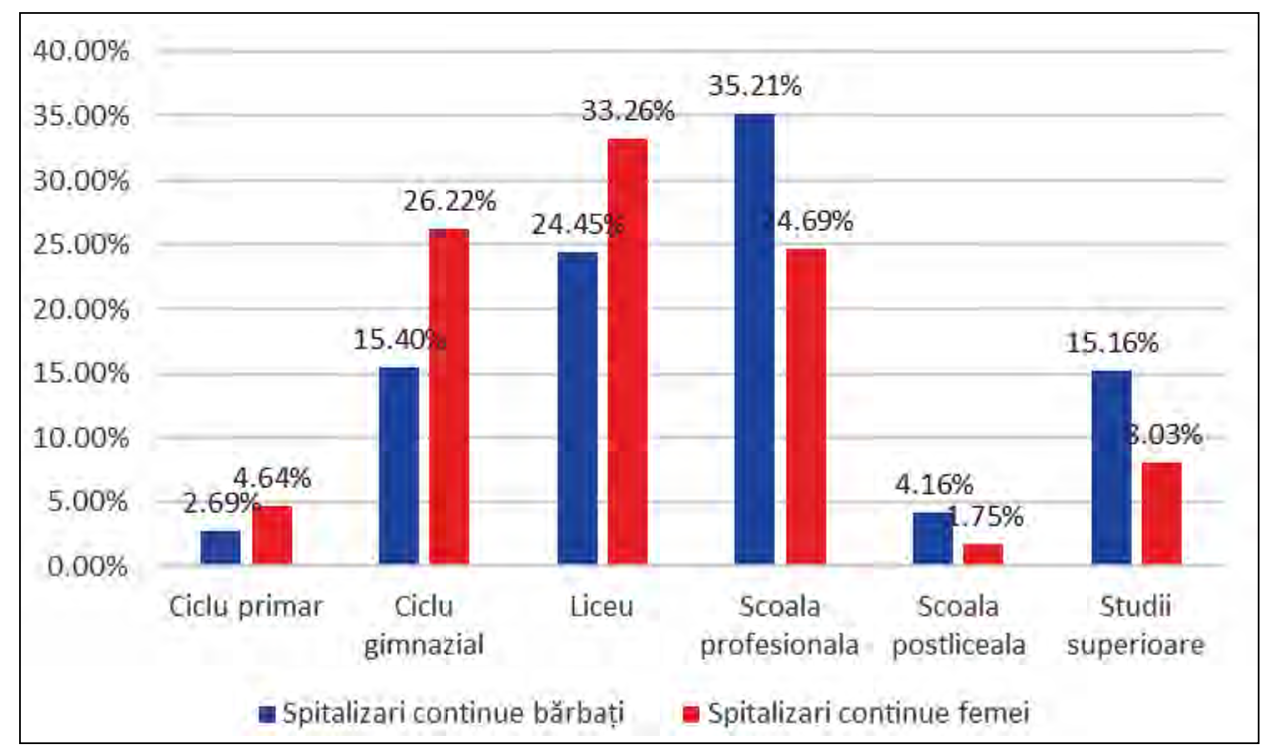

FIGURA 3. Structura lotului studiat, pe gen și nivel educaţional, pentru spitalizările continue, perioada 2015-2018

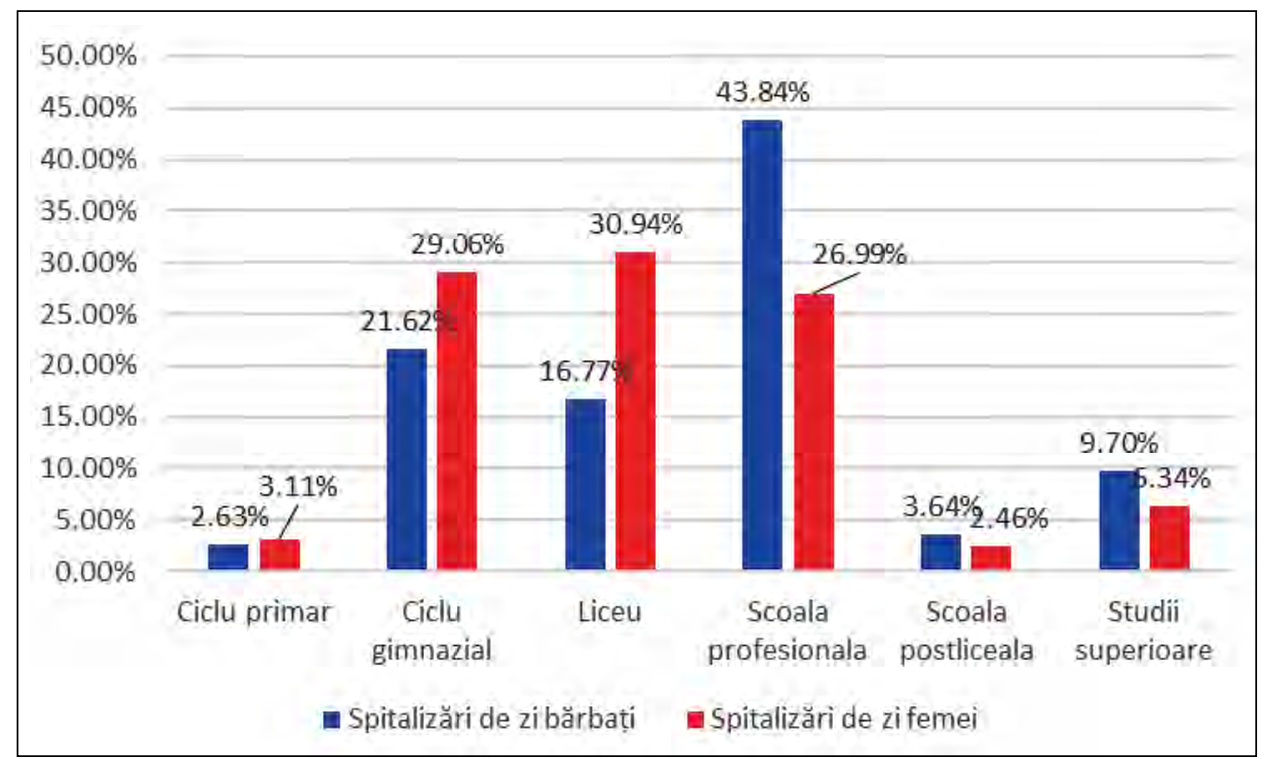

FIGURA 4. Structura lotului studiat, pe gen și nivel educaţional, pentru spitalizările de zi, perioada 2015-2018

deosebire de spitalizarea continuă, la care media de vârstă din mediul rural a fost semnificativ mai mică faţă de mediul urban (test t Student, $\mathrm{p}<0,05$ ).

Astfel, media de vârstă a pacienților din mediul urban a fost de 55,9 ani $(\mathrm{SD} \pm 8,51)$ față de vârsta medie a pacienților din mediul rural 53,99 ani $(\mathrm{SD} \pm 8,10)$ pentru spitalizarea continuă.

Pentru spitalizarea de zi, vârsta medie a pacienților din mediul urban a fost de 55,57 $(\mathrm{SD} \pm 5,36)$ ani față de vârsta medie a pacienților din mediul rural care a fost de 55,08 $(\mathrm{SD} \pm 5,5)$ ani.

Diferența între mediile de vârstă pentru mediile de rezidență urban și rural reiese din faptul că ponderea populației din mediul rural de 40-49 de ani $(24,9 \%)$ este mai mare decât ponderea populației de aceeași categorie de vârstă din mediul urban $(16 \%)$ (test $\chi 2, p<0,05)$. Pentru restul grupelor de vârstă, diferențele ponderilor nu sunt semnificative statistic

Majoritatea pacienților din București provin din sectorul 3, în care este localizat spitalul, atât pentru spitalizarea continuă, cât și pentru spitalizarea de zi.

Ponderea pacienților provenind din sectorul 3 al Municipiului București, atât pentru spitalizarea de zi, cât și pentru cea continuă, a fost semnificativ mai mare față de ponderea pacienților proveniți din alte sectoare (test $\mathrm{z}$-statistic, $\mathrm{p}<0,05$ ). $\mathrm{Nu}$ a fost evidenţiată o diferență semnificativă statistic între pacienții din sectorul 3 al municipiului București 
față de alte sectoare în ceea ce privește spitalizarea continuă sau cea de zi (test $\chi 2, p>0,05$ ).

Din punctul de vedere al statutului profesional, în urma analizei datelor colectate pentru pacienții spitalizați continuu și/sau spitalizaţi de zi in Spitalul Clinic de Psihiatrie „Dr. Constantin Gorgos“, se remarcă faptul că majoritatea sunt pensionari.

Diferențele între ponderea pensionarilor comparativ cu a altor categorii profesionale sunt semnificative statistic (test $\chi 2, p<0,05$ ), atât pentru femei, cât și pentru bărbați. $\mathrm{Nu}$ a fost evidenţiată o diferență semnificativă statistic între ponderea femeilor pensionare comparativ cu ponderea bărbaților pensionari, atât pentru spitalizarea continuă, cât și pentru spitalizarea de zi.

În spitalizarea continuă, ponderea femeilor fără ocupație a fost semnificativ mai mare decât ponderea bărbaților fără ocupație, spre deosebire de spitalizarea de zi, în care nu s-au constatat diferențe.

$\mathrm{Nu}$ s-au constatat diferențe nici pentru ponderea salariaților bărbați față de ponderea salariaților femei în spitalizarea de zi, spre deosebire de spitalizarea continuă, unde ponderea bărbaților salariați a fost semnificativ mai mare decât cea a femeilor (test $\chi 2, \mathrm{p}<0,05$ ).

Dintre femeile pensionare spitalizate în spitalizare continuă, $86 \%$ au mai puțin decât vârsta standard de pensionare din anul în care au fost spitalizate. $\mathrm{Nu}$ au fost colectate date specifice referitoare la motivul pensionării înaintea împlinirii limitei de vârstă, dar este foarte probabil ca afecțiunea pentru care au fost spitalizate să fi determinat pensionarea. Având în vedere că legislația în vigoare în domeniul pensiilor [3] prevede trecerea automată a celor pensionați pentru invaliditate la pensia pentru limită de vârstă la împlinirea vârstei standard de pensionare, putem presupune, deși avem doar o imagine transversală oferită de datele reținute în studiu, că și cei care apar ca pensionari peste vârsta standard au avut iniţial pensie de invaliditate.

Distribuția pe grupe de vârstă a femeilor și a bărbaților cu statut de pensionari este ilustrată în Figurile 5 şi 6.

Pentru bărbații spitalizați continuu, 93\% este procentul sub vârsta standard de pensionare. Diferența dintre bărbați și femei poate fi dată de diferența între vârstele standard de pensionare prevăzută de legislația în vigoare [3].

Referitor la repartizarea pe medii de rezidență, s-a constatat că nu au fost diferențe semnificative statistic între ponderea pensionarilor sau a salariaților din mediul urban față de mediul rural, dar există o diferență semnificativă între ponderea celor fără ocupație, care este mai mare în mediul rural față de mediul urban.

Pentru spitalizarea de zi, nu au fost diferențe semnificative între mediul urban și cel rural.

\section{DISCUȚII}

Din cauza faptului că se caracterizează printr-o tristețe persistentă și o lipsă de interes sau de plăcere pentru activitățile plăcute anterior, că poate perturba somnul și apetitul, că apar frecvent oboseala și lipsa de concentrare, depresia este o cauză principală a dizabilității în întreaga lume și contribuie foarte mult la povara globală a bolilor [4]. Efectele depresiei pot fi de lungă durată sau recurente și pot

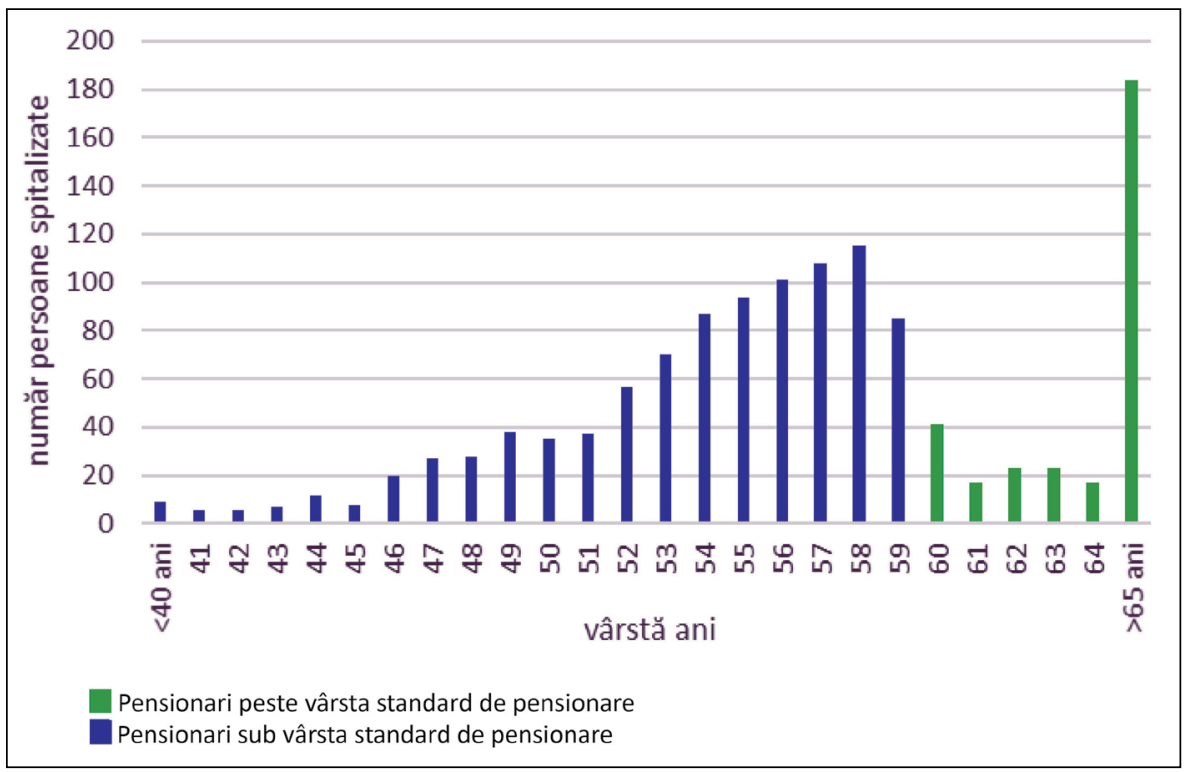

FIGURA 5. Distribuția femeilor pensionare pe vârste, perioada 2015-2018 


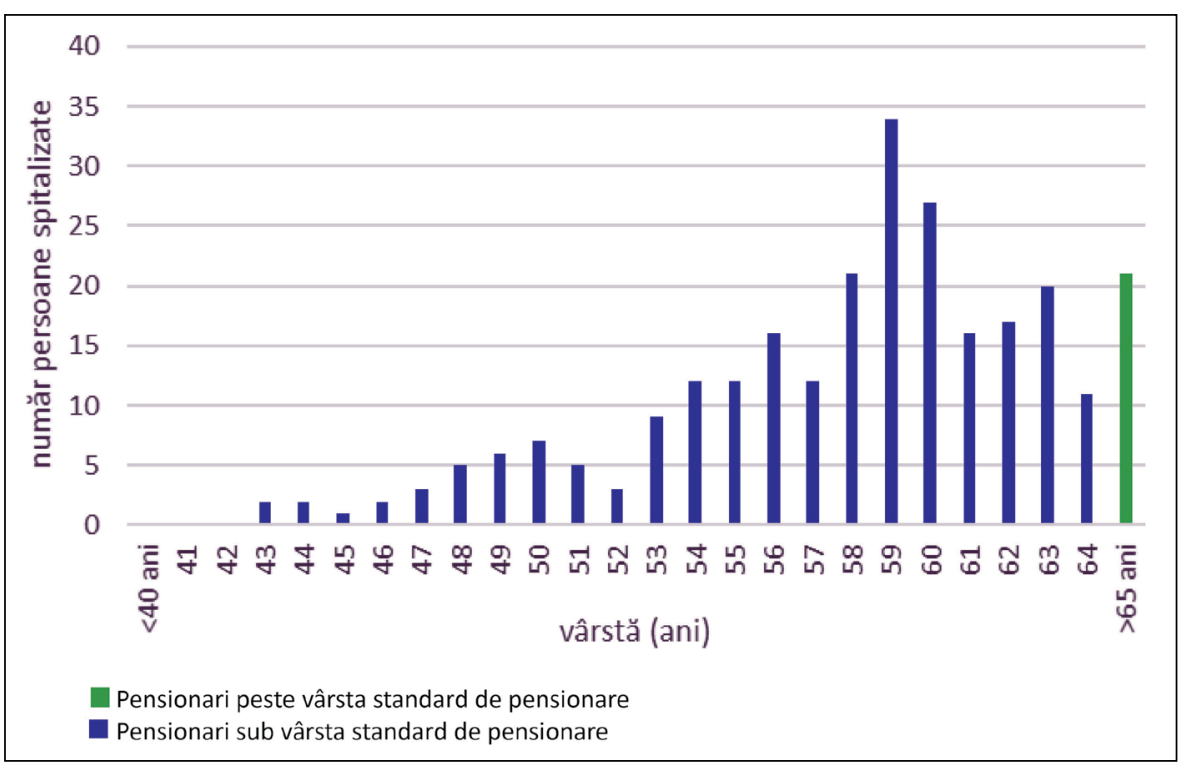

FIGURA 6. Distribuția bărbaților pensionari pe vârste, perioada 2015-2018

afecta dramatic capacitatea unei persoane de a funcționa și de a trăi cu o bună calitate a vieții.

Cauzele depresiei includ interacțiuni complexe între factorii sociali, psihologici și biologici.

Rezultatele prezentului studiu sunt asemănătoare cu rezultatele obținute în alte studii, inclusiv în studiile realizate pe eșantioane populaționale. De-a lungul timpului, mai mulți autori au găsit o prevalență dublă sau chiar triplă a tulburărilor depresive la femei față de bărbați. Astfel, Kessler şi colab. identifică această diferență între genuri în ceea ce privește morbiditatea prin depresie în SUA [5], la fel şi studiul realizat de Kornstein şi colab. [6]. O anchetă în gospodării are rezultate similare în Marea Britanie [7], iar rezultate asemănătoare sunt obținute și în Canada [8].

Alți autori au încercat să identifice cauzele acestei diferențe și au găsit că, de cele mai multe ori, un episod depresiv apare după un eveniment de viață traumatizant. $\mathrm{O}$ posibilă explicație a acestei diferențe de gen poate fi reacția diferită a femeilor față de bărbați în fața evenimentelor dificile din viață. Astfel, este mai probabil ca femeile să dezvolte, ca răspuns la stres, simptome care se încadrează în sindromul depresiv, în timp ce bărbații să își exprime mai degrabă furia sau alte forme de acțiune. În susținerea acestui fapt, studiile au arătat că diferențele de gen așteptate în morbiditatea prin tulburările depresive au fost contrabalansate de rate mai mari de abuz de alcool și dependență de droguri la bărbați $[6,7]$. Dar diferențele observate nu sunt atât de simplu de explicat, deoarece abuzul de substanțe a apărut în special la bărbații tineri și singuri, iar diferențele cele mai mari în prevalența de- presiei au apărut în special în rândul celor căsătoriți [9]. Prezentul studiu nu a explorat diferențe în ceea ce privește statusul marital sau prezența altor manifestări, ca urmare a faptului că studiul s-a bazat pe date înregistrate pentru pacienții spitalizaţi. $\mathrm{O}$ analiză detaliată ar fi posibilă doar într-un nou studiu care ar avea ca obiective explorarea influenței statusului marital sau a altor manifestări de genul abuzului de substanțe sau prezența altor manifestări psihiatrice.

O altă ipoteză susţinută de unii autori ar fi în legătură cu hormonii sexuali deoarece cele mai mari diferențe între genuri se regăsesc constant la vârstele reproductive, dar această ipoteză nu a fost clar demonstrată.

Abordări mai noi sugerează, în urma unor studii calitative, că depresia la bărbați este subestimată din cauza faptului că simptomele sunt atipice și bărbații au un comportament diferit în ceea ce privește solicitarea ajutorului de specialitate [10].

Alți factori, precum educația și venitul, au fost identificați ca având o strânsă legătura cu depresia. Astfel, un studiu efectuat în SUA [11] a arătat că grupurile populaționale cel mai puțin educate au avut cele mai mari rate ale simptomelor depresiei moderate sau severe și cele mai mici rate ale tratamentului. În prezentul studiu, a reieșit că pacienții diagnosticați cu depresie au într-o pondere mică studii superioare, ceea ce ne-a sugerat că prezența acestui diagnostic a constituit o barieră în completarea studiilor și finalizarea unui nivel superior educațional. La fel, literatura de specialitate menționează că persoanele cu venituri mari au o probabilitatea mai mică să dezvolte depresie [12]. 
Acest aspect este evidențiat pentru ambele genuri. Acelaşi studiu [12] identifică faptul de $80 \%$ dintre pacienţii cu depresie au experimentat dificultăți la locul de muncă, acasă sau în activitățile sociale din cauza simptomelor, acestea fiind similare pentru bărbați și femei (la 30\% dintre participanți dificultățile au fost moderate sau extreme). În cercetarea prezentă, nu au fost explorate dificultățile la locul de muncă, acasă sau în activitățile sociale, dar, având în vedere că au fost incluși în studiu pacienți spitalizați, dintre care majoritatea sunt pensionari înainte de vârsta standard de pensionare, putem emite ipoteza că ei au experimentat dificultăți la locul de muncă. Acest aspect ne dă o imagine asupra impactului pe care îl are depresia asupra vieții profesionale a pacienților.

\section{BIBLIOGRAFIE}

1. GBD 2017 Disease and Injury Incidence and Prevalence Collaborators. Global, regional, and national incidence, prevalence, and years lived with disability for 354 diseases and injuries for 195 countries and territories, 1990-2017: A systematic analysis for the Global Burden of Disease Study 2017. Lancet. 2018;392(10159):1789-1858.

2. Wang et al. Use of mental health services for anxiety, mood, and substance disorders in 17 countries in the WHO world mental health surveys. The Lancet. 2007;370(9590):841-50.

3. Legea $263 / 2010$ privind sistemul unitar de pensii publice.

4. World Health Organization: Prevention and promotion in mental health 2002. Available at https://www.who.int/mental_health/media/en/545. pdf.

5. Kessler RC, McGonagle KA, Zhao S, Nelson CB, Hughes M, Eshleman S, Wittchen HU, Kendler KS. Lifetime and 12-month prevalence of DSM-III-R psychiatric disorders in the United States. Results from the National Comorbidity Survey. Arch Gen Psychiatry. 1994;51(1):8-19.

6. Kornstein SG, Schatzberg AF, Thase ME, Yonkers KA, McCullough JP, Keitner GI, Gelenberg AJ, Ryan CE, Hess AL, Harrison W, Davis $\mathrm{SM}$, Keller MB. Gender differences in chronic major and double depression. J Affect Disord. 2000;60(1):1-11.

\section{CONCLUZII}

În cadrul acestui studiu, au fost identificate diferențe între subpopulațiile analizate, diferențe care au fost similare celor identificate în literatura de specialitate. Astfel, s-a constatat că au accesat serviciile medicale de psihiatrie mai multe femei decât bărbați, cea mai mare diferență între distribuții constatându-se la grupa de vârstă 50-59 de ani. O mică parte dintre pacienți au finalizat studii superioare și majoritatea dintre ei sunt pensionaţi înaintea împlinirii vârstei standard de pensionare. Cei mai mulţi dintre pacienții cu tulburare depresivă spitalizați provin din mediul urban.

Conflict of interest: none declared Financial support: none declared

7. Meltzer H, Gill B, Petticrew M, Hinds K. OCPS Surveys of Psychiatric Morbidity in Great Britain, Report 1: The prevalence of psychiatric morbidity among adults living in private households. London: Her Majesty's Stationery Office, 1995.

8. Akhtar-Danesh N, Landeen J. Relation between depression and sociodemographic factors. Int J Ment Health Syst. 2007;1(1):4.

9. Bebbington P. The origins of sex differences in depressive disorder: Bridging the gap. International Review of Psychiatry 1996; 8(4):295-332.

10. Stiawa M, Müller-Stierlin A, Staiger T, Kilian R, Becker T, Gündel H et al. Mental health professionals view about the impact of male gender for the treatment of men with depression - a qualitative study. BMC Psychiatry. 2020;20(1):276.

11. Todd M, Teitler J. Darker days? Recent trends in depression disparities among US adults. Am J Orthopsychiatry. 2019; 89(6):727-735.

12. Brody DJ et al. Prevalence of Depression Among Adults Aged 20 and Over: United States, 2013-2016, NCHS Data Brief, No. 303, February 2018. Available at https://www.cdc.gov/nchs/data/databriefs/db303. pdf. 